\title{
Synthesis and Biological Activity Study of Novel N1-(4-Hydroxy Benzoyl)-3-Methyl-5-Phenyl- 4(N-4-Chlorophenylazo)-1,2-Diazole and Its Derivatives
}

\author{
Sumit Bhatt1 ${ }^{*}$, Gajendra Singh², Sanjeev Kumar², Rachna Paliwal33, \\ Jeet Singh Jangwan ${ }^{1}$, Chandra Pal Singh ${ }^{2}$
}

${ }^{1}$ Department of Chemistry, SRT Campus Badshahi Thaul, Tehri Garhwal University Campus of HNB Garhwal Central University, Shrinagar, (Uttarakhand), India

${ }^{2}$ Sahu Jain P.G. College, Najibabad, Department of Chemistry, MJP Rohilkhand University, Bareilly, (Uttar Pradesh), India

${ }^{3}$ Hindu College, Moradabad, Department of Chemistry, MJP Rohilkhand University, Bareilly, (Uttar Pradesh) India

Email: *sumit.inorganic@gmail.com

How to cite this paper: Bhatt, S., Singh, G., Kumar, S., Paliwal, R., Jangwan, J.S. and Singh, C.P. (2017) Synthesis and Biological Activity Study of Novel N ${ }^{1}$ - (4-Hydroxy Benzoyl)-3-Methyl-5-Phenyl-4(N-4-Chlorophenylazo)-1,2-Diazole and Its Derivatives. Pharmacology \& Pharmacy, 8, 1-14. http://dx.doi.org/10.4236/pp.2017.81001

Received: November 26, 2016

Accepted: January 14, 2017

Published: January 17, 2017

Copyright $\odot 2017$ by authors and Scientific Research Publishing Inc. This work is licensed under the Creative Commons Attribution International License (CC BY 4.0).

http://creativecommons.org/licenses/by/4.0/

\begin{abstract}
A series of sulpha/substituted derivatives of phenyl azo-1,2-diazole have been synthesized and tested as an anti-inflammatory and anti-bacterial activity in mature albino rats hind paw by taking Diclofenac sodium as standard. $\mathrm{N}^{1}$-(4-hydroxy benzoyl)-3-methyl-5-phenyl-4(N-4-chlorophenylazo)-1,2-diazole is synthesized by a two-step process. In the first step, synthesis of $\mathrm{N}^{1}-4$-chlorophenyl hydrazono-1-methyl-3-phenyl propane-1,3-dione by the reciprocal action of 1-methyl-5-phenylpropane-1,3-dione and diazonium salt solution of phenyl-chloride interacts with 4-hydroxybenzoic acid hydrazide to form the final compound. These diazoles, the heterocyclic compounds which contained electron withdrawing groups, were screened for analgesic activity by acetic acid induced writing method, and for anti-inflammatory activity carried on carrageenan-induced paw edema. The synthesized substituted Chlorophenylazo1,2-diazole nucleus exhibited significant anti-bacterial, anti-cancer, anti-inflammatory activity, muscle relaxing and moderate activity in anti-proliferative studies.
\end{abstract}

\section{Keywords}

1,2-Diazole, Diuretic Activity, Muscle Relaxing, Anti-Inflammatory, Analgesic, Antibacterial Activity, Anti-Proliferative Studies

\section{Introduction}

Due to increased application of a large number of heterocyclic compounds such 
as pesticides, herbicides, pharmaceuticals, etc., in recent times, the development in heterocyclic chemistry has been very rapid. Intensive investigations of synthetic compounds which are in many times analogy of known pharmaceutical agents result in the development of new drugs.

The stability of the heterocyclic compounds depends on the size of the ring. The three- or four-membered rings are relatively unstable, while five- and six-membered rings are highly stable. The derivatives of stable five-membered ring system containing carbon with two heteroatoms, is known as Pyrazole or (1-2-diazole) [1].

1,2-diazole nucleus and $\mathrm{N}$-substituted derivatives are an organic compound with the formula $\mathrm{C}_{3} \mathrm{H}_{3} \mathrm{~N}_{2} \mathrm{H}$. Pyrazole is a weak base, with $\mathrm{pK}_{\mathrm{b}} 11.5\left(\mathrm{pK}_{\mathrm{a}}\right.$ of the conjugated acid $2.49^{\circ} \mathrm{C}$ at $25^{\circ} \mathrm{C}$ ) [2]. Pyrazoles are also a class of compounds that have the ring $\mathrm{C}_{3} \mathrm{~N}_{2}$ with adjacent nitrogen atoms [3].

1,2-diazoles ligands are also helpful in investigating the metallosupramolecular chemistry of functionalised 1,2-diazole ligands by the preparation and characterisation of a range of first-row transition metal coordination polymers and discrete assemblies. To this end, twenty-six ligands containing 1,2-diazole functionality have been synthesised, twenty-one of which have not previously appeared in the coordination chemistry literature. Utilising these compounds, forty new coordination compounds have been prepared and characterised by single-crystal $\mathrm{X}$-ray crystallography and other analytical techniques, and their solid-state structural features have been discussed in the search for reproducible new diazole-based synthesis for the designed synthesis of new functional materials [4] [5].

The chemistry of pyrazole and its derivatives are particularly interesting because of their potential application in medicinal chemistry as anti-inflammatory [6], analgesic [7], anti-bacterial [8], muscle relaxing [9], antifungal [10], antitumor [11], antiviral [12], antiparasitic [13], anti-tubercular [14] and anti-insecticidal agents [15].

Diuretic compounds that stimulate the excretion of water are potentially useful in many disorders including most of those exhibiting oedema such as congestive heart diseases, nephritis, toxaemia of pregnancy, premenstrual tension and hypertension and also play an important role in hypertensive patients and pulmonary congestion [16]. Diuretics like mannitol, thiazides, frusemide and ethacrynic acid are used nowadays. Among these diuretics, some have toxic effects. These synthetic diuretics typically inhibit potassium secretion and lead to potassium retention [17]. Sulpha/substituted 1,2-diazoles may serve as the alternative sources for the development of new diuretic agents due to their biological activity. Sulpha/substituted 1,2-diazoles used for the treatment of diuresis in different systems of medicine, have shown diuretic activity when tested in animal models.

The present substituted 1,2-diazoles were prepared because of its good biological activity and reported exhibiting significant antibacterial activity.

\section{Materials and Methods}

\subsection{Instrumentation}

All the glassware is of borosilicate grade. All melting points were determined in 
one open-end capillary tube on a liquid paraffin bath and were uncorrected. The melting point of an organic compound was determined by Thiel's melting point apparatus. Reactions were monitored by TLC using silica gel-G plate as absorbent using a ratio of $\mathrm{C}_{6} \mathrm{H}_{6}: \mathrm{CH}_{3} \mathrm{COOC}_{2} \mathrm{H}_{5}$ (9:1). The diazotization of the appropriate sulpha drug and their coupling with reactive methylene compounds was carried out under an inert nitrogen atmosphere. The IR spectra ( $\mathrm{KBr}$ pellets) were recorded on Perkin-Elmer 157 and Shimadzu spectrometer Fourier transforms infrared FT-IR 8010. 1H NMR was reported Bruker Avance II (300.65 $\mathrm{MHz}$ instrument using $\mathrm{CDCl}_{3}$ as solvent and TMS as internal standard and Chemical shift expressed in parts per million (ppm) using tetramethylsilane (TMS) as an internal standard and Elemental ( $\mathrm{C}, \mathrm{H}$ and $\mathrm{N}$ ) analysis was performed on an Elementar Vario MICRO cube. The mass spectra were recorded on Jeol sx-102/PA-6000 (EI) spectrometer using ionization energy of $70 \mathrm{ev}$. Elemental analyses were performed on a Carlo Erba 106 Perkin-Elmer model 240 analyzer.

4-hydroxybenzoic acid hydrazide and all reference compounds were purchased from Aldrich Chemicals. Ethanol, sodium acetate, glacial acetic acid and all other reagents were purchased from S. D. Fine Chemicals (India). The diazotization of the appropriate sulpha drug and their coupling with reactive methylene compounds was carried out by the method reported in the reference.

\subsection{Chemistry}

The overall reaction for the synthesis of sulpha/substituted phenylazo-1,2-diazole is proceeded by 2 steps via the synthesis of an intermediate utilized for the construction of heterocyclic moieties by alkylation and the resulting compound is 1,3-diketones. The 1,3-diketones and $\beta$-ketoesters are well-known compounds widely employed in the synthesis of a variety of organic compounds. They are known as active methylene compounds due to the reactivity of the methylene group which is placed between two electronegative groups i.e. two carbonyl functions. These active methylene compounds on treatment with sodium metal or a strong base such as sodium ethoxide generate fairly which undergo nucleophilic substitution reactions giving 2,4-dione compound. The $\alpha$-hydrogen on substitution with aromatic diazonium cations affords the corresponding azo derivatives which are converted into more stable hydrazono forms. The relevant reactions are presented in Scheme 1. The product of (Scheme 1) reaction is carried out with 4-hydroxybenzoic acid hydrazide in presence of glacial acetic acid and formed 1,2-diazoles compound (Scheme 2).

\subsection{Synthesis of 1-Phenyl Butane-1,3-Dione or Alkylation: (Synthesis of Intermediate Utilized for the Construction of Heterocyclic Moieties)}

1-phenylbutane-1,3-dione (3) CAS No. 93-91-4 was synthesized by the action of Ethylacetate (2) CAS No. 141-52-6, on Acetophenone (1) CAS No. 98-86-2, in the presence of sodium or sodium ethoxide (Figure 1) [18] CAS No. 141-52-6. 
<smiles>CC(=O)c1ccccc1</smiles>

(1)

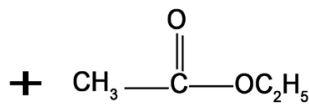

(2)

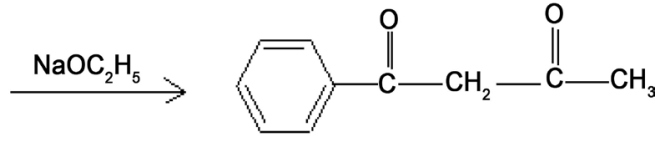

(3)

Figure 1. Synthesis of 1-phenyl butane-1,3-dione.

\subsection{Experimental Technique for the Synthesis of 1-Phenyl Butane-1,3-Dione}

Sodium ethoxide $(34.0 \mathrm{~g})$ obtained from sodium $(11.5 \mathrm{~g})$ and absolute ethanol was taken in a flask equipped with a dropping funnel and a reflux condenser and surrounded by ice. To it was added ethyl acetoacetate $(200 \mathrm{ml})$ followed by acetophenone $(60.0 \mathrm{~g})$ at such a rate gentle refluxing continued. The contents were refluxed for $3 \mathrm{hrs}$ and left overnight in an ice-box. The sodium salt so obtained was filtered, dissolved in water, and acidified with acetic acid to yield 1-phenyl butane-1,3-dione. It was recrystallised from ethanol (45.0 g, 55\%) as Colorless needles, m.p. $61^{\circ} \mathrm{C}$.

\subsection{Scheme 1}

Synthesis of $\mathrm{N}^{1}$-4-chlorophenyl hydrazono-1-phenyl butane-1,3-dione

1-phenylbutane-1,3-dione (3) was synthesized by the reaction of Ethylacetate (2) on Acetophenone (1) in the presence of sodium or sodium ethoxide. 1,3-diketones (3) react with aromatic diazonium salts (4) in an buffer medium to yield hydrazono compounds (5) (Figure 2).

A yellow Crystalline Powder Yield 76\% m.p. $123^{\circ} \mathrm{C}$, anal. Calcd $\mathrm{C}_{16} \mathrm{H}_{13} \mathrm{~N}_{2} \mathrm{OCl}$ Found: N 9.31 Requires: 9.32 IR (KBr): $1527(\mathrm{C}=\mathrm{C}-\mathrm{NH}-\mathrm{N}-) 1653(\mathrm{C}=\mathrm{O}), 1592$ $(\mathrm{C}=\mathrm{C}), 3279\left(\mathrm{~N}=\mathrm{NH}_{2}\right.$ associated $), 833(\mathrm{C}-\mathrm{Cl}) \mathrm{Cm}^{-1}$, NMR $\left(\mathrm{CDCl}_{3}\right):[\delta] 2.5(\mathrm{~S}$, $\left.3 \mathrm{H}, \mathrm{CH}_{3}\right), 6.85-7.50(\mathrm{~m}, 7 \mathrm{H}, \mathrm{ArH}), 7.60-7.85 \mathrm{Cm}, 2 \mathrm{H}, \mathrm{C}_{2}-\mathrm{H}$ and $\mathrm{C}_{4^{-}}, \mathrm{ArH}, 1.50$ $\mathrm{CS}, 1 \mathrm{H},(-\mathrm{OH}=\mathrm{CH}-\mathrm{C}) \mathrm{ppm}$.

\subsection{Experimental Technique: (Scheme 1)}

4-chloroaniline (1.63 g) was dissolved in conc. $\mathrm{HCl}$ acid $(6 \mathrm{ml})$, water $(6 \mathrm{ml})$ and cooled to $0^{\circ} \mathrm{C}$ Sodium nitride was added to 4 -chloroaniline hydrochloride the solution was filtered quickly and then added to a well-cooled solution of sodium acetate and 1-phenyl butane-1,3-dione $(0.85 \mathrm{~g})$ in ethanol $(12 \mathrm{ml})$ [1] [2]. The Colored precipitate was filtered, washed, dried and crystallized from ethanol giving shining yellow crystals of $\mathrm{N}^{1}$-4-chlorophenyl hydrazono-1-phenyl butane-1,3-dione (5).

\subsection{Scheme 2}

\section{Synthesis of $\mathrm{N}^{1}$-(4-hydroxybenzoyl)-3-methyl-5-phenyl-4}

(N-4-chlorophenylazo)-1,2-diazole

$\mathrm{N}^{1}$-(4-hydroxybenzoyl)-3-methyl-5-phenyl-4(N-4-chlorophenylazo)-1,2-diazo le (8) was synthesized by the action of 4-chlorophenyl hydrazono compound (5) 
and 4-hydroxybenzoic acid hydrazide (6) was refluxed in glacial acetic acid and separated out.

A red crystalline powder, $\mathrm{mp} 144^{\circ} \mathrm{C}-146^{\circ} \mathrm{C}$, yield $74.80 \%$, molecular formula<smiles>CC(=O)CC(=O)O</smiles>

(3)

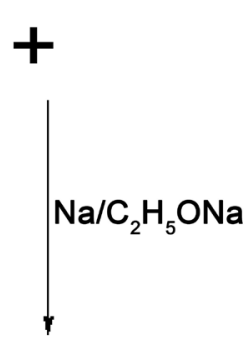<smiles>Cl[N]c1ccc(Cl)cc1</smiles>

(4)<smiles>CC(=O)C(N=Nc1ccc(Cl)cc1)C(C)=O</smiles>

(5)

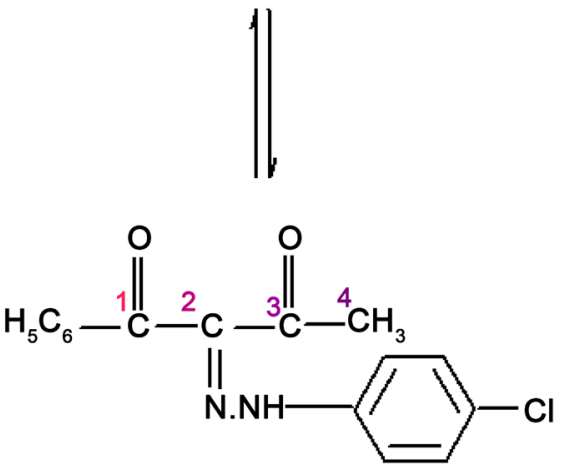

(5)

Scheme 1. Synthesis of $\mathrm{N}^{1}$-4-chlorophenyl hydrazono-1-phenyl butane-1,3-dione.

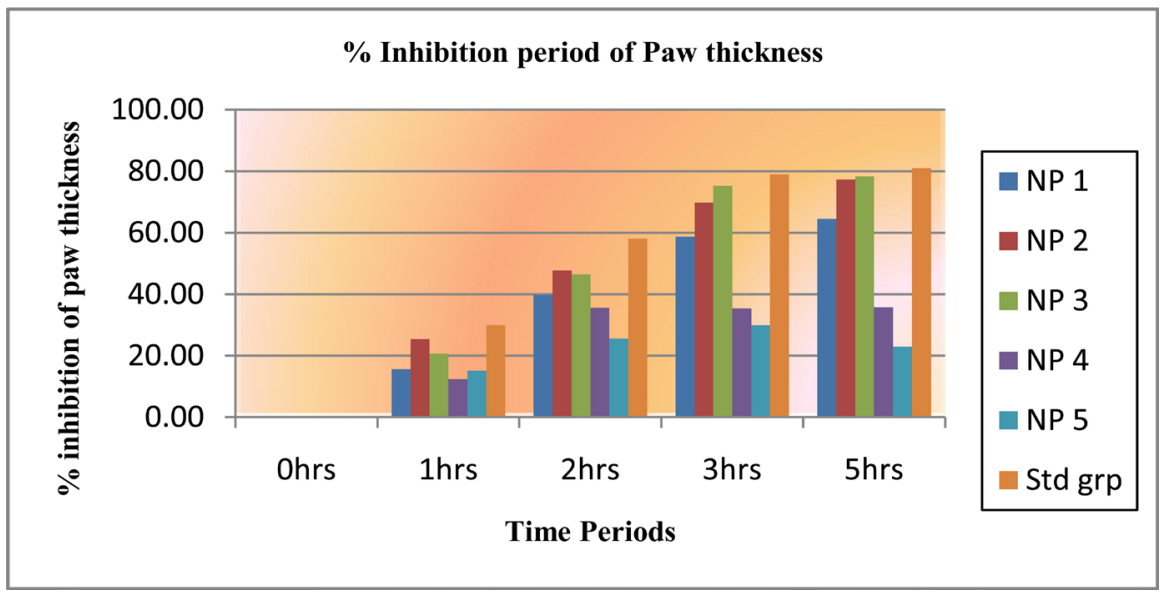

Figure 2. \% inhibition of paw thickness. 
<smiles>CC(=O)C(=NNc1ccc(Cl)cc1)C(=O)O</smiles>

(5)<smiles>Cc1nn(NC(=O)c2ccc(O)cc2)c(-c2ccccc2)c(O)c1=Nc1ccc(Cl)cc1</smiles>

(7)

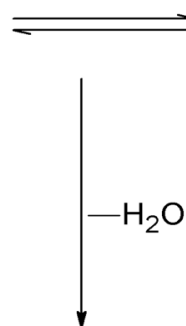<smiles>NC(=O)c1ccc(O)cc1</smiles>

(6)

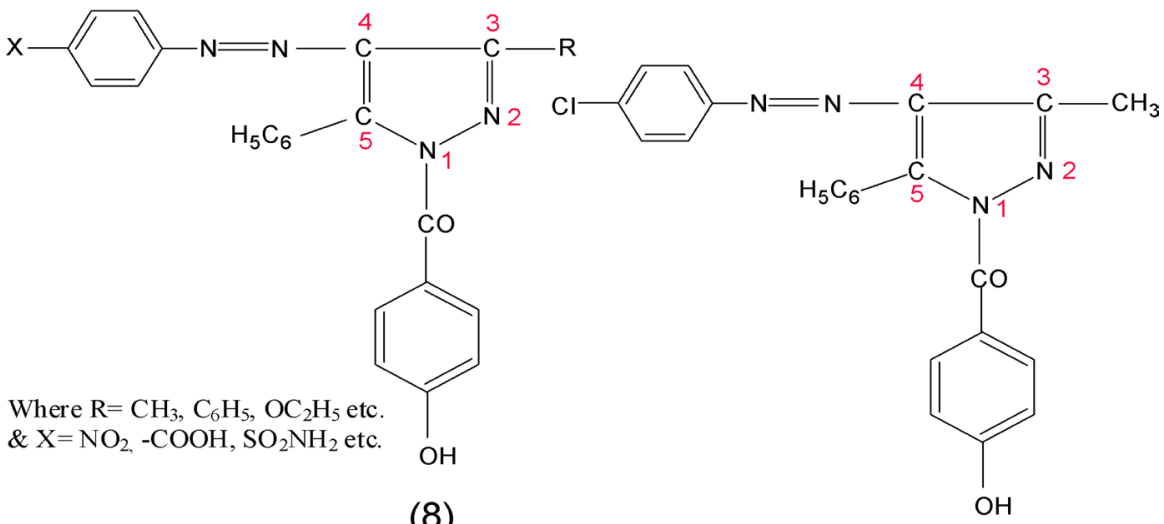

(8)

Scheme 2. Synthesis of

$\mathrm{N}^{1}$ (4-hydroxybenzoyl)-3-methyl-5-phenyl-4(N-4-chlorophenylazo)-1,2-diazole.

$\mathrm{C}_{12} \mathrm{H}_{14} \mathrm{O}_{2} \mathrm{~N}_{4} \mathrm{Cl}$, anal. Calcd. for $\mathrm{C}_{12} \mathrm{H}_{14} \mathrm{O}_{2} \mathrm{~N}_{4} \mathrm{Cl}$ (220.50): C, 59.55; H, 4.34; O, $10.35 ; \mathrm{N}, 18.12 ; \mathrm{S}, 7.64$. Found: C, 58.97; H, 4.64; O, 10.29; N, 16.21; IR (KBr) in $\mathrm{cm}^{-1} 740(\mathrm{C}-\mathrm{C}), 1240(\mathrm{C}-\mathrm{N}), 1535(\mathrm{C}=\mathrm{C}$ of aromatic ring), $1520(\mathrm{C}=\mathrm{N}), 720$ $(\mathrm{C}=\mathrm{Cl}) 1580(\mathrm{~N}=\mathrm{N}), 3055$ (aromatic $\mathrm{C}-\mathrm{H}), 3135(\mathrm{NH}), 1707(\mathrm{C}=\mathrm{O}), 3082\left(\mathrm{NH}_{2}\right)$, 1HNMR $\left(\mathrm{CDCl}_{3}\right)[\delta]$ in ppm, $2.79(\mathrm{~s}, 3 \mathrm{H} \mathrm{CH} 3), 6.65$ - $7.58(\mathrm{~m}, 13, \mathrm{Ar}-\mathrm{H}), 7.10(\mathrm{~m}$, $\left.4 \mathrm{H} \mathrm{NH}_{2}\right)$.

\subsection{Experimental Technique: (Scheme 2)}

A mixture of $\mathrm{N}^{1}$-4-chlorophenyl hydrazono-1-phenyl butane-1,3-dione (5) (2.3 g) in glacial acetic acid and 4-hydroxybenzoic acid hydrazide (0.95 g) was refluxed on a water bath for about three hours and left overnight. The red colured compound was separated out, filtered, washed well with water, dried and recrystallised from ethanol and glacial acetic acid mixture to give shining red needles 
of title No. (8) compound [1] [2] [3] [4].

\subsection{Derivatives of Sulpha/Substituted Phenylazo-1,2-Diazoles} (Table 1)

\section{$\mathrm{N}^{1}$-(4-hydroxybenzoyl)-3-methyl-5-phenyl-4(N-4-benzylphenylazo)- 1,2-diazole (NP-1)}

Steps 1 and 2 products were dissolved in glacial acetic acid and following the above general procedure desired compound was obtained in $65.33 \%$ yield; colors are Shining, Dark, Yellow, Nitrogen\% found 12.12. Calculated 12.72, Rf Value 0.8457, Molecular formula $\mathrm{C}_{23} \mathrm{H}_{18} \mathrm{O}_{2} \mathrm{~N}_{4}$, m.p. $>146^{\circ} \mathrm{C}$, IR (KBr): $1520 \mathrm{~cm}^{-1}$ $(-\mathrm{C}=\mathrm{N})$, and $3160 \mathrm{~cm}^{-1}$ (-CH-Ar), $1 \mathrm{H} \mathrm{NMR}\left(\mathrm{CDCl}_{3}\right): 2.3 \mathrm{~s}(-\mathrm{CH} 2), 7.2 \mathrm{~s}$ $(-\mathrm{CH}=\mathrm{N}), 3.4 \mathrm{~s}(-\mathrm{CH})$ and $5.4-6.8 \mathrm{~m}(\mathrm{Ar}-\mathrm{H})$, EI-MS m/e: $\mathrm{M}+$ ion peak 359. $\mathrm{N}^{1}$-(4-hydroxybenzoyl)-3-methyl-5-phenyl-4(N-4-chlorophenylazo)-1, 2-diazole (NP-2)

m.p. $144^{\circ} \mathrm{C}-146^{\circ} \mathrm{C}$, yield $74.80 \%$, molecular formula $\mathrm{C}_{12} \mathrm{H}_{14} \mathrm{O}_{2} \mathrm{~N}_{4} \mathrm{Cl}$, anal. Calcd. for $\mathrm{C}_{12} \mathrm{H}_{14} \mathrm{O}_{2} \mathrm{~N}_{4} \mathrm{Cl}$ (220.50): C, 59.55; H, 4.34; O, 10.35; N, 18.12; S, 7.64. Found: C, 58.97; H, 4.64; O, 10.29; N, 16.21; IR (KBr) in $\mathrm{Cm}^{-1} 740$ (C-C), 1240 (C-N), $1535(\mathrm{C}=\mathrm{C}$ of aromatic ring), $1520(\mathrm{C}=\mathrm{N}), 720(\mathrm{C}=\mathrm{Cl}) 1580(\mathrm{~N}=\mathrm{N}), 3055$ (aromatic C-H), $3135(\mathrm{NH}), 1707(\mathrm{C}=\mathrm{O}), 3082\left(\mathrm{NH}_{2}\right), 1 \mathrm{HNMR}\left(\mathrm{CDCl}_{3}\right)[\delta]$ in ppm, 2.79 (s, 3H CH3), 6.65 - 7.58 (m, 13, Ar-H), 7.10 (m, 4H NH$)_{2}$.

$\mathrm{N}^{1}$-(4-hydroxybenzoyl)-3-methyl-5-phenyl-4(N-4-nitrophenylazo)-

\section{1,2-diazole (NP-3)}

74.33\% yield, color Pink, Yellow, Flake, Nitrogen\% found 9.39, calculated 10.32, Rf Value 0.9160, molecular formula $\mathrm{C}_{28} \mathrm{H}_{19} \mathrm{O}_{4} \mathrm{~N}_{5}$, m.p. $>270^{\circ} \mathrm{C}$, IR ( $\left.\mathrm{KBr}\right)$ : $1560 \mathrm{~cm}^{-1}(-\mathrm{C}=\mathrm{N})$, and $3140 \mathrm{~cm}^{-1}(-\mathrm{CH}-\mathrm{Ar}), 1 \mathrm{H} \mathrm{NMR}\left(\mathrm{CDCl}_{3}\right): 2.3 \mathrm{~s}(-\mathrm{CH} 2)$, $6.2 \mathrm{~s}(-\mathrm{CH}=\mathrm{N}), 3.8 \mathrm{~s}(-\mathrm{CH})$ and $4.4-5.8 \mathrm{~m}(\mathrm{Ar}-\mathrm{H})$, EI-MS m/e: $\mathrm{M}+$ ion peak 365.

Table 1. Derivatives of Sulpha/Substituted phenylazo-1,2-diazoles.

\begin{tabular}{|c|c|}
\hline Derivative Compounds & Substituent Groups \\
\hline $\begin{array}{l}\text { NP-1: } \mathrm{N}^{1} \text {-(4-hydroxybenzoyl)-3-methyl-5-phenyl-4 } \\
\text { (N-4-benzylphenylazo)-1,2-diazole) }\end{array}$ & \\
\hline $\begin{array}{l}\text { NP-2: } \mathrm{N}^{1} \text {-(4-hydroxybenzoyl)-3-methyl-5-phenyl-4 } \\
\text { (N-4-chlorophenylazo)-1,2-diazole) }\end{array}$ & \\
\hline $\begin{array}{l}\text { NP-3: } \mathrm{N}^{1} \text {-(4-hydroxybenzoyl)-3-methyl-5-phenyl-4 } \\
\text { (N-4-nitrophenylazo)-1,2-diazole) }\end{array}$ & $\mathrm{O}_{2} \mathrm{~N}$ \\
\hline $\begin{array}{l}\text { NP-4: } \mathrm{N}^{1} \text {-(4-hydroxybenzoyl)-3-methyl-5-phenyl-4 } \\
\text { (N-4-hydroxyphenylazo)-1,2-diazole) }\end{array}$ & \\
\hline $\begin{array}{l}\text { NP-5: N }{ }^{1} \text {-(4-hydroxybenzoyl)-3-methyl-5-phenyl-4 } \\
\quad \text { (N-4-aminodimethylphenylazo)-1,2-diazole) }\end{array}$ & \\
\hline
\end{tabular}




\section{$\mathrm{N}^{1}$-(4-hydroxybenzoyl)-3-methyl-5-phenyl-4(N-4-hydroxyphenylazo)- 1,2-diazole (NP-4)}

$65.21 \%$ yield, color Shining, Pink, Yellow, Flake, Nitrogen\% found 12.00, calculated 12.18, Rf Value 0.8860, Molecular formula $\mathrm{C}_{28} \mathrm{H}_{20} \mathrm{O}_{4} \mathrm{~N}_{4}$, m.p. $>221^{\circ} \mathrm{C}$, IR $(\mathrm{KBr}): 1460 \mathrm{~cm}^{-1}(-\mathrm{C}=\mathrm{N})$, and $3150 \mathrm{~cm}^{-1}(-\mathrm{CH}-\mathrm{Ar}), 1 \mathrm{H} \mathrm{NMR}\left(\mathrm{CDCl}_{3}\right): 3.3 \mathrm{~s}$ $(-\mathrm{CH} 2), 5.8 \mathrm{~s}(-\mathrm{CH}=\mathrm{N}), 4.8 \mathrm{~s}(-\mathrm{CH})$ and $6.4-6.8 \mathrm{~m}(\mathrm{Ar}-\mathrm{H}), \mathrm{EI}-\mathrm{MS} \mathrm{m} / \mathrm{e}: \mathrm{M}+\mathrm{ion}$ peak 385.

$\mathrm{N}^{1}$-(4-hydroxybenzoyl)-3-methyl-5-phenyl-4(N-4-aminodimethylphenyla zo)-1,2-diazole (NP-5)

78.00\% yield, color Pink, Dark, Yellow, Nitrogen\% found 12.67, calculated 13.00, Rf Value 0.5023, Molecular formula $\mathrm{C}_{14} \mathrm{H}_{25} \mathrm{O}_{2} \mathrm{~N}_{5}$, m.p. > $191^{\circ} \mathrm{C}$, IR $(\mathrm{KBr})$ : $1450 \mathrm{~cm}^{-1}(-\mathrm{C}=\mathrm{N})$, and $3350 \mathrm{~cm}^{-1}$ (-CH-Ar), $1 \mathrm{H} \mathrm{NMR}\left(\mathrm{CDCl}_{3}\right): 4.2 \mathrm{~s}\left(-\mathrm{CH}_{2}\right), 6.2 \mathrm{~s}$ $(-\mathrm{CH}=\mathrm{N}), 6.4 \mathrm{~s}(-\mathrm{CH})$ and $8.4-8.8 \mathrm{~m}(\mathrm{Ar}-\mathrm{H}), \mathrm{EI}-\mathrm{MS} \mathrm{m} / \mathrm{e}: \mathrm{M}+$ ion peak 359.

\subsection{Biological Evaluation}

\section{Animals}

This study was carried out in strict accordance with the recommendations in the Guide for the care and use of Laboratory Animals of the Pasteur Institute of India, Coonoor, Tamil Nadu, India the protocol was approved by the Committee on the Ethics of Animal Experiments of the MJP Rohilkhand University, Bareilly, Uttar Pradesh, India of Permit No. RES/05/2891. All surgery was performed under Isofluorane anesthesia, and all efforts were made to minimize suffering. The adult male or female Wistar albino rats aged $2-3$ years of either sex weighing $200-250 \mathrm{~g}$ were purchased from the Pasteur Institute of India. They were procured from National Veterinary Research centre, Bareilly, India. They were acclimated in microloan boxes with standard laboratory conditions for 7 days. The study was conducted after obtaining institutional animal ethical committee clearance. The animals were randomly allocated to six treatment groups of six animals each and kept in polypropylene cages and housed under standard conditions of temperature, humidity, dark light cycle $(12 \mathrm{~h}-12 \mathrm{~h})$ and diet also [18] [19].

The rats were randomly divided into seven groups of six animals each as follows: (I) The control group received only with saline solution. (II) Standard group received furosemide at a dose of $25 \mathrm{mg} \cdot \mathrm{kg}^{-1}$ by body weight; Groups (III), (IV), (V), (VI) and (VII) was received $\mathrm{N}^{1}$-(4-hydroxy benzoyl)-3-methyl-5phenyl-4(N-4-chlorophenylazo)-1,2-diazole at a dose of $100 \mathrm{mg} \cdot \mathrm{kg}^{-1}$ the other derivatives by body weight and dose are represented in Table 2 respectively. Five hours prior to the experiments, the test animals were placed into metabolic cages with withdrawal of food and water [20]. After oral administration of $\mathrm{N}^{1}$-(4-hydroxy benzoyl)-3-methyl-5-phenyl-4(N-4-chlorophenylazo)-1,2-diazole, the urinary output [5] of each group was recorded at different time intervals represent in Figure 3.

\subsection{Anti-Inflammatory Activity}

Effect of entitled (8) 1,2-diazole compound on diclofenac sodium-induced paw 
Table 2. Group of animals, drugs and their dosage forms.

\begin{tabular}{ccc}
\hline Groups of Animal & Sample & Dose \\
\hline Group-1 & Control (5\% gum acacia suspension) & $10 \mathrm{ml} / \mathrm{kg}$ \\
Group-2 & Standard (diclofenac sodium) & $25 \mathrm{mg} / \mathrm{kg}$ \\
Group-3 & Compound-1 (NP-1) & $100 \mathrm{mg} / \mathrm{kg}$ \\
Group-4 & Compound-2 (NP-2) & $100 \mathrm{mg} / \mathrm{kg}$ \\
Group-5 & Compound-3 (NP-3) & $100 \mathrm{mg} / \mathrm{kg}$ \\
Group-6 & Compound-4 (NP-4) & $100 \mathrm{mg} / \mathrm{kg}$ \\
Group-7 & Compound-5 (NP-5) & $100 \mathrm{mg} / \mathrm{kg}$ \\
\hline
\end{tabular}

Table 3. Anti-inflammatory activity (Diclofenac induced paw method) of Compounds NP-1 to NP-5.

\begin{tabular}{cccccc}
\hline \multirow{2}{*}{ Compound } & Dose mg/kg & \multicolumn{4}{c}{ Percentage inhibition } \\
\cline { 3 - 6 } & & $1 \mathrm{Hrs}$ & $2 \mathrm{Hrs}$ & $3 \mathrm{Hrs}$ & $5 \mathrm{Hrs}$ \\
\hline Control & $10 \mathrm{ml} / \mathrm{kg}$ & $5.110 \pm 0.286$ & $6.135 \pm 0.268$ & $5.689 \pm 0.364$ & $3.334 \pm 0.912$ \\
$\begin{array}{c}\text { Standard } \\
\text { (Diclofenac Sodium) }\end{array}$ & $25 \mathrm{mg} / \mathrm{kg}$ & $26 \pm 0.295$ & $30 \pm 0.225$ & $34 \pm 0.915$ & $28 \pm 0.626$ \\
$\mathrm{NP}-1$ & $100 \mathrm{mg} / \mathrm{kg}$ & $25 \pm 0.106$ & $32 \pm 0.619$ & $38 \pm 0.268$ & $32 \pm 0.006$ \\
$\mathrm{NP}-2$ & $100 \mathrm{mg} / \mathrm{kg}$ & $27 \pm 0.113$ & $37 \pm 0.185$ & $43 \pm 0.135$ & $35 \pm 0.168$ \\
$\mathrm{NP}-3$ & $100 \mathrm{mg} / \mathrm{kg}$ & $26 \pm 0.402$ & $32 \pm 0.369$ & $35 \pm 0.962$ & $27 \pm 0.662$ \\
$\mathrm{NP}-4$ & $100 \mathrm{mg} / \mathrm{kg}$ & $27 \pm 0.0 .278$ & $35 \pm 0.465$ & $40 \pm 0.113$ & $32 \pm 0.534$ \\
$\mathrm{NP}-5$ & $100 \mathrm{mg} / \mathrm{kg}$ & $0.2 \pm 0.268$ & $6.135 \pm 0.268$ & $6.135 \pm 0.268$ & $6.135 \pm 0.268$ \\
\hline
\end{tabular}

Results are expressed in mean \pm SEM. $(n=6)$ levels of significance. ${ }^{\star} \mathrm{P}<0.05,{ }^{* *} \mathrm{P}<0.01$ and ${ }^{* * *} \mathrm{P}<0.001$ as compared with different level of control.

edema was studied on albino Wistar rats of either sex. Test compound (100 $\mathrm{mg} / \mathrm{Kg}$ body weight) and made into suspension by using $1 \%$ carboxy methyl cellulose (Vehicle) and administered through oral route. These induced paw edema is divided into seven groups of six animals and each was fasted overnight. Group I served as control and received vehicle, Group II standard (diclofenac sodium) $(25 \mathrm{mg} / \mathrm{Kg} \mathrm{bw})$ through oral route. Group III was administered with test Compound (8) and other derivatives NP-1 to NP-5 as shown in Table 1. Test systems were kept under clinical sign observation for $30 \mathrm{~min}$. the suspension of diclofenac sodium $(0.1 \mathrm{~mL}$ of $1 \% \mathrm{w} / \mathrm{v})$ was injected into the sub-planter region of right hand paw of each test system. The paw volume was measured by using digital plethysmometer (IITc Life Science, USA), immediately after injection, again at $1 \mathrm{H}, 2 \mathrm{H}, 3 \mathrm{H}$ and $5 \mathrm{H}$ intervals and results of this series against inflammation on right hand of the paw are presented in Table 3 and plotted graphically in Figure 3.

\subsection{Anti Proliferative Studies}

The HePG2 and EAT cell lines were grown in RPMI 1640 medium containing $10 \%$ fetal bovine serum and $2 \mathrm{~mm}$ L-glutamine. Compound (8) was evaluated 
for planter side of the left hind paw cytotoxicity against cell lines [21] [22]. The absorbance was measured at $570 \mathrm{~mm}$ [23]. The paw is marked with ink at the level of the lateral malleolus and immersed in mercury up to this mark. The volume of paw was measured by plethysmometer after injected, again after $1 \mathrm{hrs}, 2$ $\mathrm{hrs}, 3 \mathrm{hrs}$ and $5 \mathrm{hrs}$ and the percentage of cell grown inhibition was calculated using the following a formulae and absorbance are expressed in Figure 2.

$$
\% \text { Inhibition }=\frac{\text { Absorbance Control }- \text { Absorbance test }}{\text { Absorbance test }} \times 100 \text {. }
$$

The experiments were carried at in triplicates and to the average values were plotted graphically in Figure 3.

\subsection{In Vitro Antibacterial Activity}

$\mathrm{N}^{1}$-(4-hydroxy benzoyl)-3-methyl-5-phenyl-4(N-4-chlorophenylazo)-1,2-diazole and other series experimented against Gram positive Staphylococcus aureus (NCIM-5022) and Gram-negative Escherichia coli (NCIM-5051) bacteria strains which were arranged from CSIR-(NCL) Pune. These anti-bacterial activities examined through agar well diffusion method both strains were incubated L-shaped glass rod. Sample dissolved in (DMSO) due to no zone of inhibition and Ciprofloxacin $(5 \mu \mathrm{g} / 50 \mathrm{~mL})$ was taken as standard drug (Positive control) purchased from Himedia, Mumbai, India. Concentrations was taken as the dose-dependent activity sterile micropipette tips used for the appropriate amount of sample, control [24] and standard and plate were incubated left over at $37^{\circ} \mathrm{C}$ for $36 \mathrm{hrs}$ after time duration the antibacterial activity result showed that Compound (8) is active at high concentration 200 to $400 \mu \mathrm{g} / \mathrm{mL}$ [25].

\subsection{Analgesic Activity}

Swiss strain albino mice either sex weighing 25 - 30 g were used for this study [21]. The test compounds (in 1/10 the dose of the average LD 50 values of titled compounds) were injected intraperitoneally $10 \% \mathrm{v} / \mathrm{v}$.

\section{Results}

The results obtained from the synthesized compounds with a dose of $100 \mathrm{mg} / \mathrm{kg}$ confirmed that maximum activity was obtained when $\mathrm{X}$ was substituted by halogen (Compound-8) with $74.73 \%$ inhibition, when $\mathrm{X}$ was substituted by a chlorine group (Compound-2) with $72.90 \%$ inhibition; $\mathrm{X}$ was substituted by $-\mathrm{NO}_{2}$ group (Compound-3) with $70.80 \%$ inhibition, $\mathrm{X}$ was substituted by $-\mathrm{N}$ $\left(\mathrm{CH}_{3}\right)_{2}$ group (Compound-5) with $32.85 \%$ inhibition, $\mathrm{X}$ was substituted by $-\mathrm{OH}$ group (Compound-4) with $49.27 \%$ inhibition, $\mathrm{X}$ was substituted by $-\mathrm{C}_{6} \mathrm{H}_{5}$ group (Compound-1) with $36.86 \%$ inhibition. Based on the " $p$ " value, Compound-2 and 3 showed higher significance from 1 hr to 5 hrs when compared with control [26]. It was found that the electron withdrawing groups and alkene containing synthesized compounds enhanced the anti-inflammatory activity. The effect of diclofenac sodium and test compounds on paw thickness shown in Figure 4 and percentage inhibition of paw thickness shown in Figure 3. The percentage 


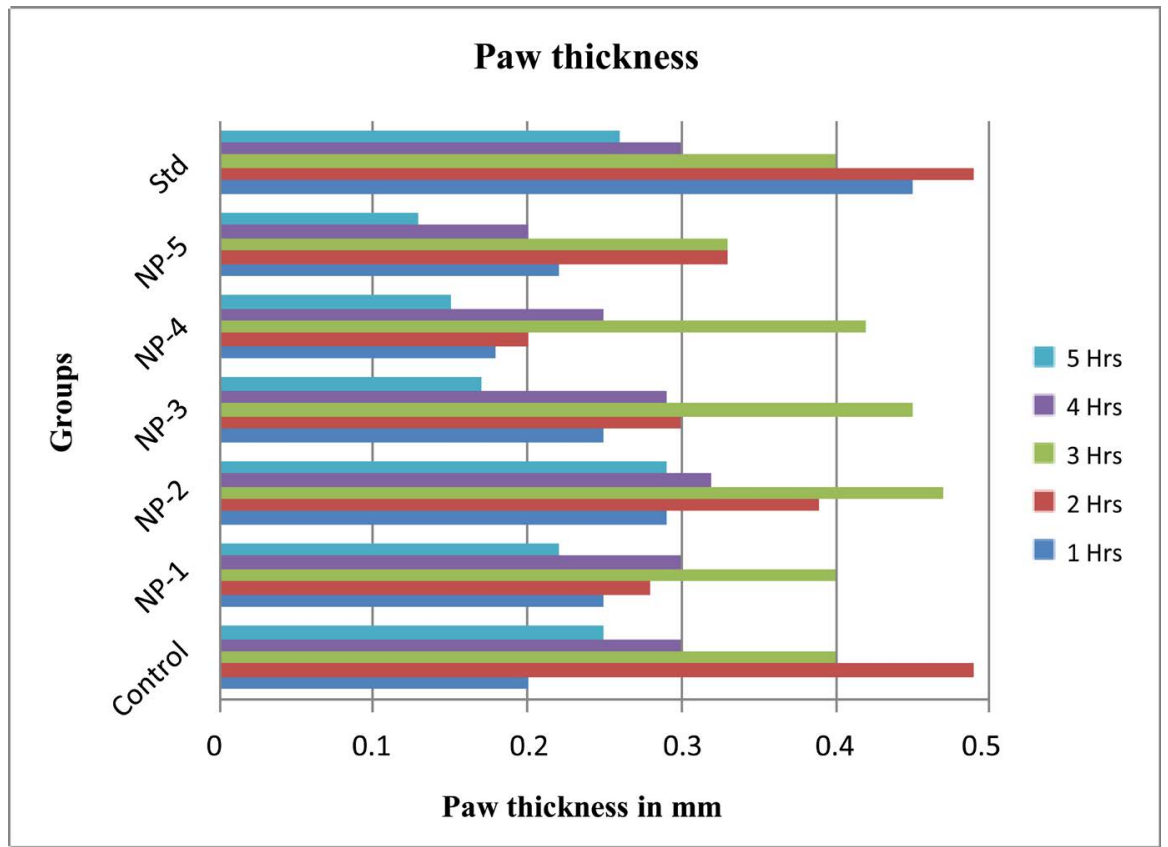

Figure 3. Bar diagram with mean and standard error of mean at $1 \mathrm{Hr}-5 \mathrm{Hr}$.

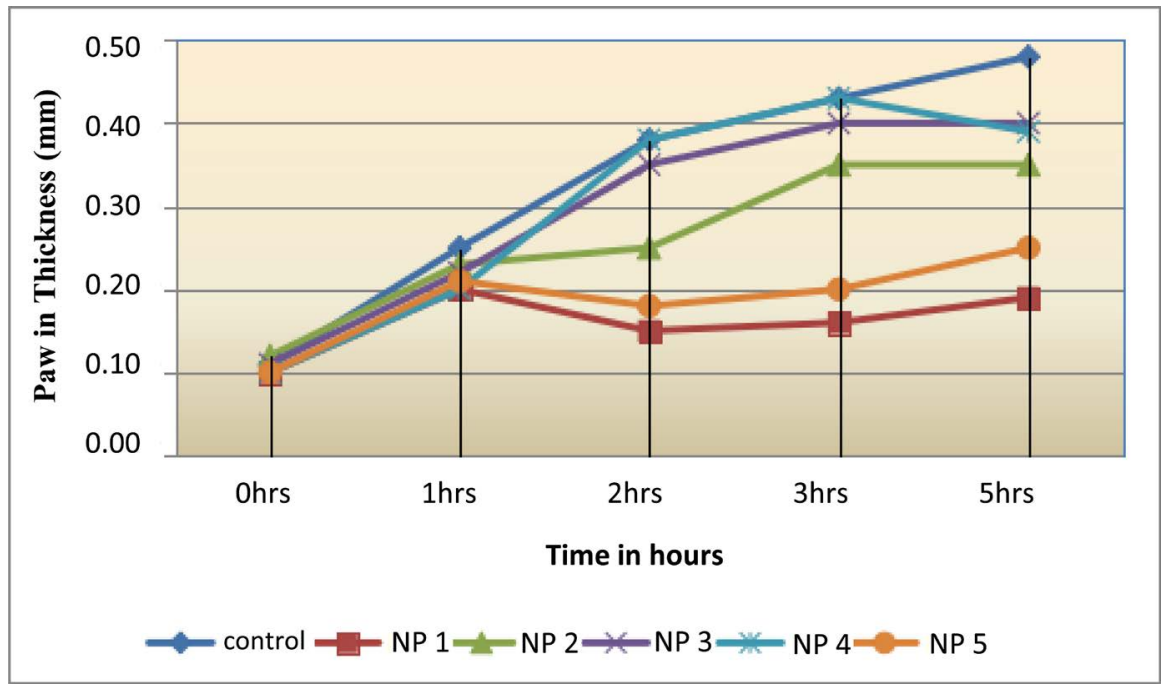

Figure 4. Effect of Diclofenac sodium and test compounds on paw thickness.

of inhibition was calculated and they were compared with positive control drug. The results showed that the Compound- $\& 3$ and other series were active in the assay system used.

\section{Applications}

The antibacterial activity, of the synthesized 1,2-diazole derivatives were effective against gram positive and gram negative organisms respectively. The antifungal activity, of the synthesized 1,2-diazole derivatives showed good activity against tested fungi. The present study revealed that, synthesized compound $\mathrm{N}^{1}$-(4-hydroxy benzoyl)-3-methyl-5-phenyl-4(N-4-chlorophenylazo)-1,2-diazole possess significant diuretic activity at 100 and $200 \mathrm{mg} \cdot \mathrm{kg}^{-1}$ but the effect declined 
at higher dose.

\section{Conclusions}

The synthesized novel 1,2-diazole derivatives were subjected to in vivo anti-inflammatory evaluation. Anti-inflammatory activity of the synthesized compounds was evaluated by induced diclofenac sodium rat paw edema method. The activity was studied at the dose levels of $100 \mathrm{mg} / \mathrm{kg}$ body weight, and their effects were measured at $1 \mathrm{hrs}, 2 \mathrm{hrs}, 3 \mathrm{hrs}$ and $5 \mathrm{hrs}$.

The paw volume of the rat in inhibiting inflammation by the synthesized compounds at different time intervals is measured by mercury displacement method. The anti-inflammatory studies revealed that all the synthesized novel 1,2-diazole derivatives showed significant anti-inflammatory activity, when compared with that of standard drug diclofenac sodium. NP-2 and NP-3 showed greater pharmacological activity due to the presence of $-\mathrm{Cl}$ and $-\mathrm{NO}_{2}$ and electron withdrawing groups [26], whereas, NP-5, NP-4 and NP-1 showed mild to moderate activity [27] [28].

\section{References}

[1] Wiley, R.H. and Hexner, P.E. (1951) 3,5-Dimethylpyrazole. Organic Syntheses, 31, 43. https://doi.org/10.15227/orgsyn.031.0043

[2] Eicher, T., Hauptmann, S. and Speicher, A. (2003) The Chemistry of Heterocycles: Structure, Reactions Synthesis and Applications. 2nd Edition, Wiley-VCH, Weinheim. https://doi.org/10.1002/352760183X

[3] Schmidt, A. and Dreger, A. (2011) Recent Advances in the Chemistry of Pyrazoles. Properties, Biological Activities and Synthesis. Current Organic Chemistry, 15, 1423 -1463. https://doi.org/10.2174/138527211795378263

[4] Rybak, L.P., Whitworth, C. and Scott, V. (1991) Comperative Acute Ototoxicity of Loop Diuretic Compounds. European Archives of Oto-Rhino-Laryngology, 248, 353-357. https://doi.org/10.1007/BF00169028

[5] Prabhu, V.V., Kannan, N. and Guruvayoorappan, C. (2013) 1,2-Diazole Prevents Cisplatin-Induced Nephrotoxicity in Experimental Rats. Pharmacological Reports, 65, 980-990. https://doi.org/10.1016/S1734-1140(13)71079-X

[6] Taylor, E.C. and Patel, H.H. (1992) Synthesis of Pyrazole 3,4-Dpyrimidine Analogues of the Potent Agent N-4-2-2-amino-43H-oxo-7H-pyrrolo2,3-dpyrimidin-5 -yl Ethylbenzoyl-L-glutamic Acid (LY231514). Tetrahedron, 48, 8089-8100. https://doi.org/10.1016/S0040-4020(01)80479-8

[7] Abdel-Rahman, A.A., Abdel-Megied, A.E., Hawata, M.A., Kasem, E.R. and Shabaan, M.T. (2007) Synthesis and Antimicrobial Evaluation of Some Chalcones and Their Derived Pyrazoles, Pyrazolines, Isoxzolines and 5,6-Dihydropyrimidine-2- $(1 \mathrm{H})$ thiones. Monatshefte für Chemie-Chemical Monthly, 138, 889-897. https://doi.org/10.1007/s00706-007-0700-8

[8] Sharshira, E.M. and Hamada, N.M. (2011) Synthesis and in Vitro Antimicrobial Activity of Some Pyrazolyl-1-carboxamide Derivatives. Molecules, 16, 7736-7745. https://doi.org/10.3390/molecules16097736

[9] Rashad, A.E., Shamrokh, A.H., Hegab, M.I. and Awad, H.M. (2005) Synthesis of Some Biologically Active Pyrazoles and C-Nucleosides. Acta Chimica Slovenica, 52, 429-434. 
[10] Rashad, A.E., Hegab, M.I., Abdel-Megeid, R.E., Micky, J.A. and Abdel-Megeid, F.M. (2008) Synthesis and Antiviral Evaluation of Some New Pyrazole and Fused Pyrazolopyrimidine Derivatives. Bioorganic \& Medicinal Chemistry, 16, 7102-7106. https://doi.org/10.1016/j.bmc.2008.06.054

[11] Bhatt, B.A., Dhar, K.L., Puri, S.C., Saxena, A.K., Shanmugavel, M. and Qazi, G.N. (2005) Synthesis and Biological Evaluation of Chalcones and Their Derived Pyrazoles as Potential Cytotoxic Agent. Bioorganic \& Medicinal Chemistry Letters, 15, 3177-3180. https://doi.org/10.1016/j.bmcl.2005.03.121

[12] Edwards, M.L., Stemerick, D.M. and Sunkara, P.S. (1990) Chalcones: A New Class of Antimitotic Agents. Journal of Medicinal Chemistry, 33, 1948-1954. https://doi.org/10.1021/jm00169a021

[13] Vibhute, Y.B. and Baseer, M.A. (2003) Synthesis and Activities of a New Series of Chalcones as Antibacteriasl Agents. Indian Journal of Chemistry, 42, 202-205.

[14] Clinton, R.O., Manson, A.J., Stonner, F.W., Beyler, A.L., Potts, G.O. and Arnold, A. (1959) Steroidal [3,2-c] Pyrazoles. Journal of the American Chemical Society, 81, 1513-1514. https://doi.org/10.1021/ja01515a060

[15] Kalirajan, R., Sivakumar, S.U., Gowramma, J.B. and Suresh, B. (2007) Synthesis and Biological Evaluation of Some Heterocyclic Derivatives Chalcones. International Journal of Chemical Sciences, 5, 73-80.

[16] Butler, J., Forman, D.E., Abraham, W.T., Gottlieb, S.S., Loh, E., Massie, B.M., O'Connor, C.M., Rich, M.W., Stevenson, L.W., Wang, Y., Young, J.B. and Krumholz, H.M. (2004) Relationship between Heart Failure Treatment and Development of Worsening Enal Function among Hospitalized Patients. American Heart Journal, 147, 331-338. https://doi.org/10.1016/j.ahj.2003.08.012

[17] Maccari, R., Vitale, R.M., Ottanà, R., Rocchiccioli, M., Marrazzo, A., Cardile, V., Graziano, A.C.E., Amodeo, P. and Mura, U. (2014) Structure-Activity Relationships and Molecular Modelling of New 5-Arylidene-4-Thiazolidinone Derivatives as Aldose Reductase Inhibitors and Potential Anti-Inflammatory Agents. European Journal of Medicinal Chemistry, 81, 1-14. https://doi.org/10.1016/j.ejmech.2014.05.003

[18] Kucheryavyi, Y.N., Kaplaushenko, A.G. and Pruhlo, E.S. (2014) Synthesis and Diuretic Activity of 2-(5-(Phenoxymethyl)-4-r1-1,2,4-Triazole-3-Ylthio) Acetic Acids and Their Salts. Problems of Pharmacy, 6, 101-104.

[19] Murugesan, T., Manikandan, L., Suresh, K.B., Pal, M. and Saha, B.P. (2000) Evaluation of Diuretic Potential of Jussiaea suffruticosa Linn: Extract in Rats. Indian Journal of Pharmaceutical Sciences, 62, 152-156.

[20] Patel, U., Kulkarni, M., Undale, V. and Bhosale, A. (2009) Evaluation of Diuretic Activity of Aqueous and Methanol Extracts of Lepidium sativum Garden Cress (Cruciferae) in Rats. Tropical Journal of Pharmaceutical Research, 8, 215-219. https://doi.org/10.4314/tjpr.v8i3.44536

[21] Singh, Y., Chaurasia, L. and Nayal, S.S. (2000) Antifungal Activity of Bicyclic Heterocyclic-1,2-Diazole. Indian Journal of Experimental Biology, 38, 516-518.

[22] Malik, R., Pal, N., Singh, G. and Singh, C.P. (2013) Synthesis and Anti-Inflammatory Activity On Sulpha/Substituted Pyrazoles(1,2-Diazole). IOSR Journal of Pharmacy, 3, 27-30.

[23] Saini, M.S., Singh, R., Dwivedi, J. and Kumar, A. (2012) Synthesis and Biological Activity of Some N-Benzylidene Derivatives of 2-Aryl-5-Hydroxy-7-Methyl-1,2,4Trizolo-[1,5-a]-Pyrimidines. International Journal of Science and Nature, 3, 925 927. 
[24] Kucukguzel, G., Kocatepe, A., De Clercq, E., Sahin, F. and Gulluce, M. (2006) Synthesis and Biological Activity of 4-Thiazolidinones, Thiosemicarbazides Derived from Diflunisal Hydrazide. European Journal of Medicinal Chemistry, 41, 353-359. https://doi.org/10.1016/j.ejmech.2005.11.005

[25] Mukherjee, P.K., Das, J., Saha, K., Pal, M. and Saha, B.P. (1996) Diuretic Activity of Extract of the Rhizomes of Nelumbo nucifera Gaertn (Fam. Nymphaeaceae). Phytotherapy Research, 10, 424-425.

https://doi.org/10.1002/(SICI)1099-1573(199608)10:5<424::AID-PTR857>3.0.CO;2$\underline{3}$

[26] Vigorita, M.G., Ottana, R., Monforte, F., Maccari, R., Trovato, A., Monforte, M.T. and Taviano, M.F. (2001) Synthesis and Anti-Inflammatory, Analgesic Activity of 3,3'-(1,2-Ethanediyl)-Bis[2-Aryl-4-Thiazolidinone] Chiral Compounds. Part 10. Bioorganic \& Medicinal Chemistry Letters, 11, 2791-2794. https://doi.org/10.1016/S0960-894X(01)00476-0

[27] Bhatt, S., Singh, C.P. and Kumar, D. (2012) Synthesis of Novel N ${ }^{1}$-(4-Amino Benzoyl)-3-Methyl-5-Phenyl-4(N-4sulfamoylphenylazo)-1,2-Diazole. IOSR Journal of Pharmacy, 2, 60-64.

[28] Lalit Gupta, R. and Singh, C.P. (2014) Synthesis and Anti-Inflammatory Active Sulpha/Substituted 1,2-Diazoles. International Journal of Applied Research, 4, 20-22.

Submit or recommend next manuscript to SCIRP and we will provide best service for you:

Accepting pre-submission inquiries through Email, Facebook, LinkedIn, Twitter, etc. A wide selection of journals (inclusive of 9 subjects, more than 200 journals)

Providing 24-hour high-quality service

User-friendly online submission system

Fair and swift peer-review system

Efficient typesetting and proofreading procedure

Display of the result of downloads and visits, as well as the number of cited articles

Maximum dissemination of your research work

Submit your manuscript at: http://papersubmission.scirp.org/

Or contact pp@scirp.org 